\title{
Vertical tectonic motions in the Lesser Antilles: linking short- and long-term observations
}

\author{
E.M. van Rijsingen ${ }^{1}$, E. Calais ${ }^{1,2,3}$, R. Jolivet ${ }^{1,2}$, J.-B. de Chabalier ${ }^{4}$, R. Robertson ${ }^{5}$, G.A. Ryan ${ }^{5,6}$, \\ and S. Symithe ${ }^{7}$ \\ ${ }^{1}$ Department of Geosciences, École Normale Supérieure, CNRS UMR 8538, PSL Université, Paris, France. ${ }^{2}$ Institut \\ Universitaire de France, Paris, France. ${ }^{3}$ Université Côte d'Azur, Institut de Recherche pour le Développement, \\ CNRS, Observatoire de la Côte d'Azur, Géoazur, France. ${ }^{4}$ Institut de Physique du Globe de Paris, CNRS UMR 7154, \\ Université de Paris, Paris, France. ${ }^{5}$ Seismic Research Centre, University of the West Indies, Saint Augustine, \\ Trinidad and Tobago. ${ }^{6}$ Montserrat Volcano Observatory, Flemmings, Montserrat. ${ }^{7}$ URGéo Laboratory, State \\ University of Haiti, Port-au-Prince, Haiti
}

This manuscript is a preprint uploaded to EarthArxiv. This preprint has been submitted for publication and has not yet been peer-reviewed. We welcome feedback, discussion and comments at any time. Feel free to get in touch with one of the authors.

Corresponding author: Elenora van Rijsingen

Email: e.m.vanrijsingen@gmail.com

Twitter: @tectonora 


\section{Vertical tectonic motions in the Lesser Antilles: linking short-}

\section{2 and long-term observations}

3 E.M. van Rijsingen ${ }^{1}$, E. Calais ${ }^{1,2,3}$, R. Jolivet ${ }^{1,2}$, J.-B. de Chabalier ${ }^{4}$, R. Robertson ${ }^{5}$, G.A.

$4 \quad$ Ryan $^{5,6}$, and S. Symithe ${ }^{7}$

$5{ }^{1}$ Department of Geosciences, École Normale Supérieure, CNRS UMR 8538, PSL Université,

6 Paris, France

$7 \quad{ }^{2}$ Institut Universitaire de France, Paris, France

8 3'Université Côte d'Azur, Institut de Recherche pour le Développement, CNRS, Observatoire de

9 la Côte d'Azur, Géoazur, France

$10{ }^{4}$ Institut de Physique du Globe de Paris, CNRS UMR 7154, Université de Paris, Paris, France

115 Seismic Research Centre, University of the West Indies, Saint Augustine, Trinidad and Tobago

$12{ }^{6}$ Montserrat Volcano Observatory, Flemmings, Montserrat

$13{ }^{7}$ URGéo Laboratory, State University of Haiti, Port-au-Prince, Haiti

15 ABSTRACT

16 It has been proposed that interseismic coupling along the Lesser Antilles subduction interface

17 could be responsible for subsidence observed over the past 125,000 to 100 years inferred from

18 geological data on Quaternary coral terraces and active micro-atolls in the central part of the arc.

19 However, horizontal GNSS velocities show that the Lesser Antilles subduction zone is currently

20 experiencing low interseismic coupling, meaning that little to no elastic strain currently builds up

21 as the North- and South American plates subduct beneath the Caribbean plate. Here we show,

22 using modern geodetic data, a general subsidence of the Lesser Antilles island arc at 1-2 mm/yr 
23 over the past 20 years, in agreement with the $\sim 100$-year trend of $1.3 \pm 1.1 \mathrm{~mm} / \mathrm{yr}$ subsidence

24 derived from coral micro-atolls in eastern Martinique. Using elastic dislocation models, we show 25 that a locked, or partially locked subduction interface would produce uplift of the island arc, 26 opposite to present-day and recent geological observations, hence supporting a poorly-coupled

27 subduction. This subsidence since at least $125 \mathrm{ka}$ is in line with the extensional tectonics observed 28 along the arc since the mid-Miocene. The margin-wide subsidence is therefore likely controlled 29 by large-scale geodynamic processes that operate over the long-term. Such processes could also 30 play a role in tuning the aseismic character of the subduction megathrust, which appears to be a 31 long-term feature.

\section{INTRODUCTION}

34 The accumulation of stresses along locked subduction interfaces over timescales of tens to 35 hundreds of years (i.e., short-term) leads to horizontal and vertical deformation of the overriding 36 plate (e.g., Savage et al., 1983; Chlieh et al., 2004). Interseismic locking results in landward 37 horizontal motions in the (fore)arc and tectonic subsidence or uplift depending on the distance 38 from the trench and the structure of the overriding plate (e.g., Wallace et al., 2012, Mouslopoulou 39 et al., 2016). Such deformation is largely elastic and is balanced by coseismic and postseismic slip 40 during large earthquake sequences (Avouac, 2015). Monitoring this deformation with geodetic 41 observations therefore provides information about the ability of the subduction interface to 42 generate megathrust earthquakes (e.g., Loveless and Meade, 2011; Avouac, 2015). On longer time 43 scales (i.e., from ten thousand to several million years), convergence at subduction zones leads to 44 anelastic deformation of the overriding plate, resulting in processes such as mountain building 45 (e.g., Armijo et al., 2015; Jolivet et al., 2020) or basal erosion or accretion (e.g., Menant et al., 
2020, Boucard et al., 2021). As a result, over time scales of tens to hundreds of years plate

47 convergence is not entirely transformed into elastic, recoverable deformation, but part of it must

48 be converted into permanent strain. Understanding the interplay between such short- and long-

49 term deformation patterns and how their underlying processes tune the present-day seismogenic

50 behavior of subduction zones is fundamental for seismic hazard assessment in such contexts.

51

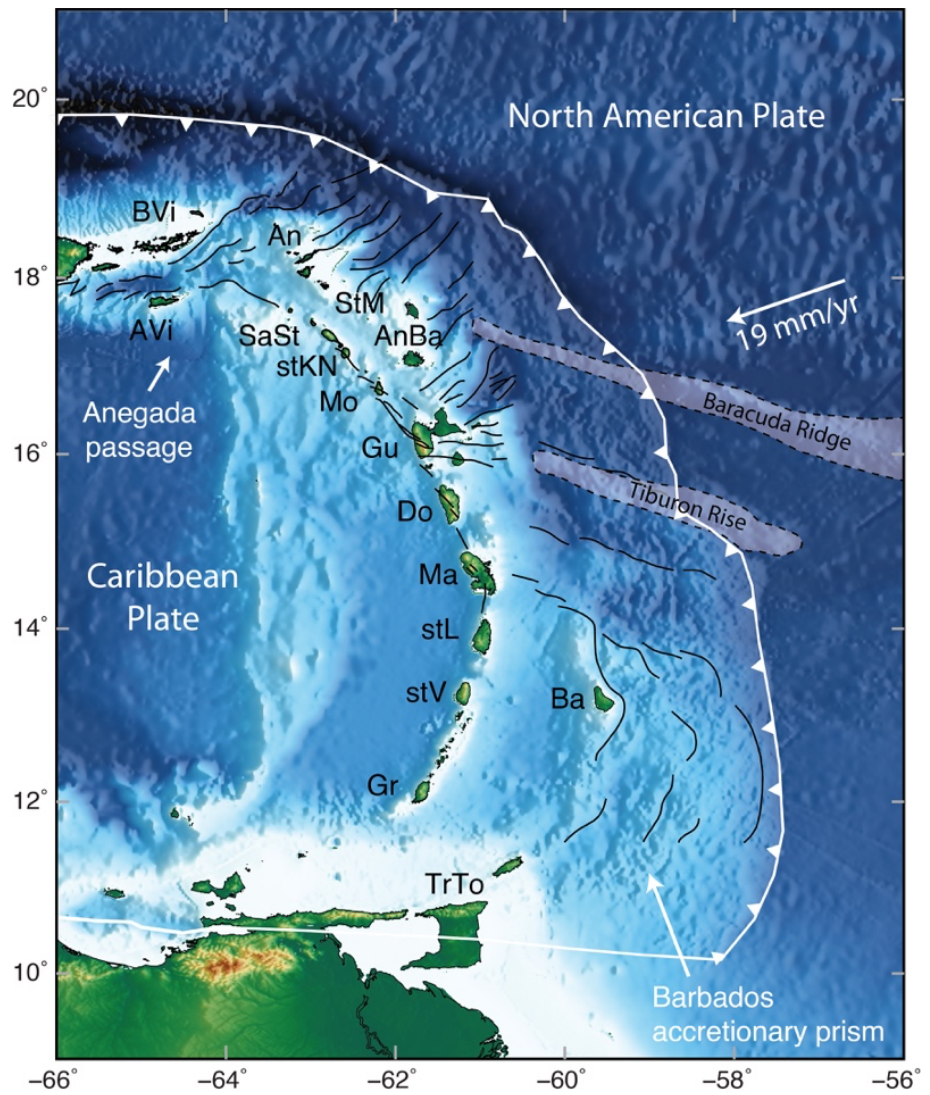

53 Figure 1. Seismotectonic setting of Lesser Antilles subduction zone. BVI, British Virgin Islands; AVI,

54 American Virgin Islands; An, Anguilla; stM, Saint Martin; SaSt, Saba \& Saint Eustatius; AnBa, Antigua

$55 \&$ Barbuda; stKN, Saint Kitts \& Nevis; Mo, Montserrat; Gu, Guadeloupe; Do, Dominica; Ma, Martinique;

56 stL, Saint Lucia; stV, Saint Vincent; Gr, Grenada; Ba, Barbados; TrTo, Trinidad \& Tobago.

57 Lesser Antilles subduction zone, which constitutes the eastern boundary of the Caribbean plate

58 (Figure 1), has not experienced any large megathrust earthquakes in the past 100 years (Stein et 
59 al., 1989). Two large historical earthquakes in the $19^{\text {th }}$ century (M7-8 in 1839 and M7.5-8.5 in

60 1843) have been interpreted by some as thrust events, but unequivocal evidence for this is missing

61 (e.g., Bernard and Lambert, 1988). Caribbean-wide geodetic studies over the past decade all found

62 low interseismic coupling of the subduction interface (Manaker et al., 2008; Symithe et al., 2015),

63 a finding recently confirmed by a more detailed study focused on the Lesser Antilles (van 64 Rijsingen et al., 2021). Their Bayesian inversion of horizontal GNSS velocities and forward 65 models show that the subduction interface is currently unlocked, with no re-locking of the 66 proposed rupture areas of the 1839-1843 earthquakes. These results however cover the last few 67 decades only; expanding temporal coverage over one or several seismic cycles requires geological 68 proxies such as coral data (e.g., Sieh et al., 2008).

70 Micro-atoll data collected in Martinique (Weil-Accardo et al., 2016) indicate tectonic subsidence 71 at $1.3 \pm 1.1 \mathrm{~mm} / \mathrm{yr}$ since 1895 , while estimates from reef terraces in Les Saintes (part of the 72 archipelago of Guadeloupe; Leclerc et al. 2014) and Martinique (Leclerc et al., 2015) indicate 73 subsidence at $0.3-0.45 \mathrm{~mm} / \mathrm{yr}$ over the past $125 \mathrm{ka}$. Therefore, at least the central part of the Lesser 74 Antilles arc has been experiencing tectonic subsidence over this time interval, an observation that 75 has been related to temporal variations in friction of an overall locked plate interface, or to the 76 accumulation of coseismic deformation from megathrusts earthquakes not compensated by 77 opposite interseismic uplift (Leclerc \& Feuilet, 2019).

79 Here we use data from continuously operating GNSS stations in the Lesser Antilles to show that 80 the island arc is currently experiencing margin-wide subsidence at $1-2 \mathrm{~mm} / \mathrm{yr}$, in agreement with 81 observations from corals. We show such subsidence does not represent a fraction of the elastic 
82 strain observed during the interseismic period over a locked subduction interface. These results

83 therefore suggest that the arc subsidence observed across several time-scales (up to 20 years for

84 GNSS, 10s-100s years for micro-atolls, $10^{3}$ to $10^{4}$ years for marine terraces) is controlled by

85 lithosphere-scale geodynamic processes and is independent from elastic deformation within the 86 earthquake cycle.

87

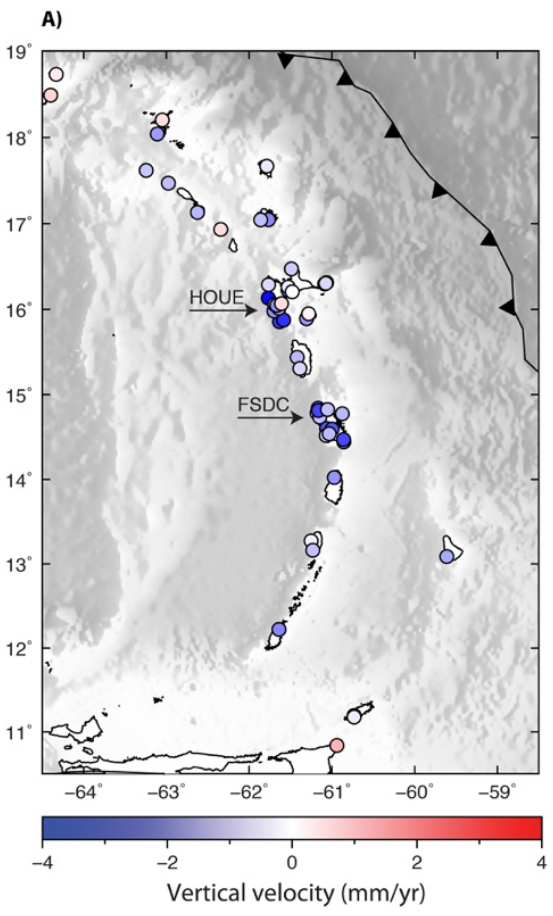

B)

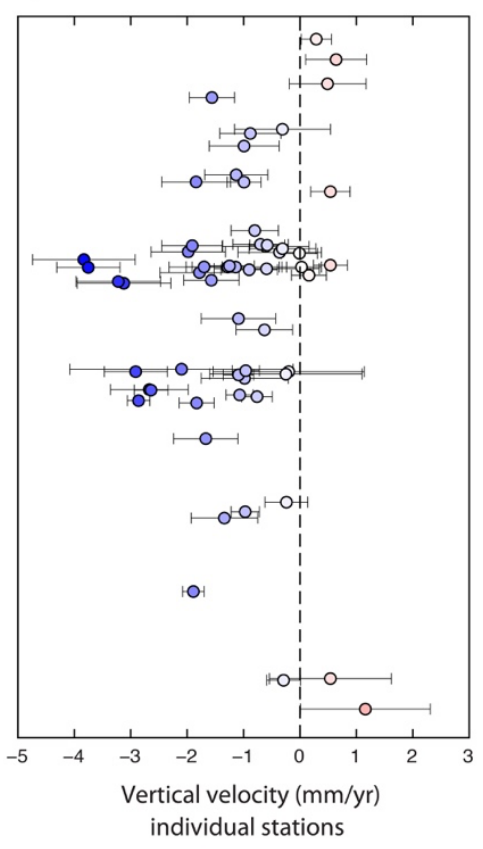

c)

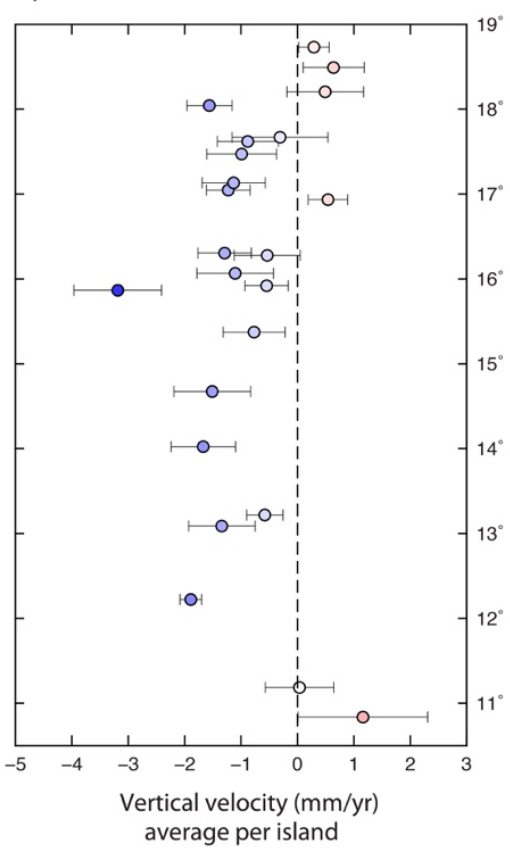

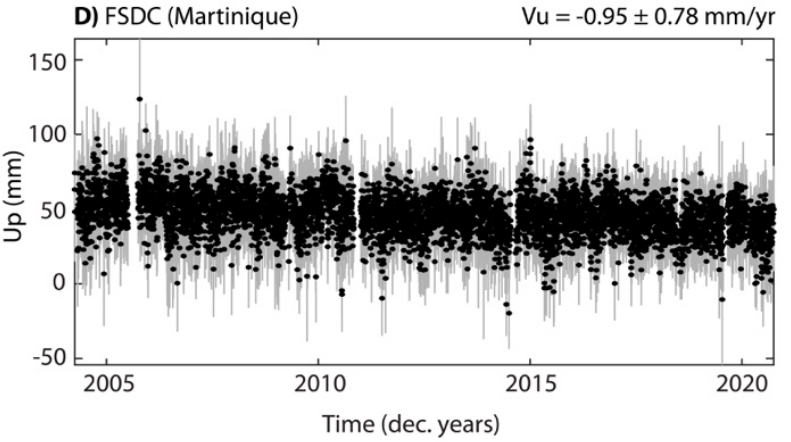

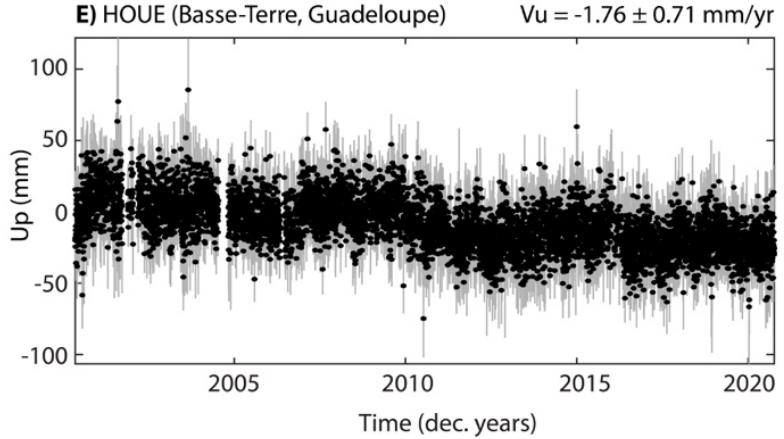

88

89 Figure 2. Vertical tectonic motions of the Lesser Antilles islands. A) Vertical velocity per GNSS station in map view. B) Vertical velocities ordered by latitude (vertical axis) and amplitude (horizontal axis). C) 
91 Average velocity per island, calculated as a weighted average based on the time series length. D) Time

92 series vertical component station FSDC (Martinique). E) Time series vertical component station HOUE 93 (Basse-Terre, Guadeloupe).

\section{VERTICAL GNSS CONFIRMS UNCOUPLED SUBDUCTION INTERFACE}

96 The GNSS data used in this study were processed as described in van Rijsingen et al. (2021), with

97 longer time series so as to covers the 1994-2020 time interval. The vertical velocities used in this

98 paper were computed using a least-squares fit of the data with a functional form that includes a

99 linear trend, seasonal and semi-seasonal oscillations, and step functions at times when offsets are

100 reported (equipment change or local earthquakes) or visually detected. We used the First-Order

101 Gauss-Markov Extrapolation algorithm (Herring, 2003; Reilinger et al., 2006) to obtain velocity

102 uncertainties that account for time-correlated noise in the time series.

103

104 Vertical motions at the 53 GNSS stations with at least three years of continuous data (Figure 2A)

105 show a general pattern of subsidence of the Lesser Antilles, while islands at the edges of the 106 subduction (i.e., the Virgin Islands in the North and Trinidad in the South) show uplift. The islands 107 of Guadeloupe and Martinique, for which station density is highest, show subsidence rates between $1080 \pm 0.3$ to $3.8 \pm 0.9 \mathrm{~mm} / \mathrm{yr}$ (Figure $2 \mathrm{~B}$ ), in good agreement with a recent study by Sakic et al. 109 (2020) who found similar vertical velocities from two independent geodetic solutions. The 110 variability likely results from local site conditions, but mostly from variations in time series 111 duration amongst GNSS stations. We therefore use the time series duration to calculate a weighted 112 average for each island (Figure 2C) and find a homogeneous pattern of subsidence at 1-2 $\mathrm{mm} / \mathrm{yr}$ 113 along the arc, with an overall average rate of $1.1 \pm 0.6 \mathrm{~mm} / \mathrm{yr}$. This subsidence is in agreement 114 with observations from micro-atolls in Martinique over the past 125 years (i.e., $1.3 \pm 1.1 \mathrm{~mm} / \mathrm{yr}$; 
115 Weil-Accardo et al., 2016), and has an amplitude similar to that observed at other subduction zones

116 (e.g., Vannucchi et al., 2013). The subsidence derived from micro-atolls has been interpreted as

117 the result of interseismic locking of the subduction interface or coseismic displacements during

118 megathrust earthquakes (Weil-Accardo et al., 2016; Leclerc et al., 2015). However, the agreement

119 between the "geological" subsidence and the "geodetic" one, while the subduction interface 120 currently has very low interseismic coupling (van Rijsingen et al., 2021), is an indication that they

121 result from processes that are not related to the elastic earthquake deformation cycle. In the 122 following, we therefore calculate how much vertical deformation one should expect from 123 interseismic loading along the plate interface using forward models with various interseismic 124 locking depths.

126 We use the model setup of van Rijsingen et al. (2021), which uses the Slab2 geometry (Hayes et 127 al., 2018) and a layered semi-infinite elastic medium (Zhu and Rivera, 2002) based on Schlaphorst 128 et al. (2018). We test three different scenarios of homogeneous interplate locking, using downdip 129 limits of the seismogenic zone at 20, 40 and $65 \mathrm{~km}$ (Figure 3). Using these locking patterns, we 130 calculate vertical deformation at the locations of GNSS stations along the arc. As can be observed 131 in Figure 3A, a shallow locking down to $20 \mathrm{~km}$ does not result in any significant vertical 132 deformation at most of the islands, a consequence of their large distance to the locked portion of 133 the subduction interface. Increasing the downdip limit of the locked interface to $40 \mathrm{~km}$ (Figure 3B) 134 results in uplift of most islands at rates of 1-2 mm/yr. Only some islands in the South, such as Saint 135 Vincent, the Grenadines and Grenada, where the slab dip is shallower and the arc is thus located 136 further away from the trench, do not show any uplift or subsidence. The third scenario, a 137 homogeneously locked interface down to $65 \mathrm{~km}$ depth, proposed by Bie et al. (2020), is a deep 
138 end-member compared to the global range $(51 \pm 9 \mathrm{~km}$; Heuret et al., 2011). This model shows 139 subsidence at the islands located above the coupled area (i.e., from south to north: Tobago, 140 Barbados, Basse-Terre, La Désirade, Antigua, Barbuda, Anguilla, and Saint Martin) and uplift at 1410.2 to $1.3 \mathrm{~mm} / \mathrm{yr}$ further west along the present-day volcanic arc (Figure $3 \mathrm{C}$ ). We find results 142 similar to those described above when performing the forward model calculations for an alternative 143 slab geometry (Bie et al.,2020), which becomes steeper at larger depths compared to the Slab2 144 model (Figure S1).

146 This simple experiment leads to two conclusions. First, we observe that deep or intermediate 147 interseismic locking of the plate interface would result in present-day uplift of the islands at rates 148 that would be detectable by GNSS (Figure 3), whereas geodetic and micro-atoll observations both 149 show subsidence in the $1-2 \mathrm{~mm} / \mathrm{yr}$ range (Figure $2 \mathrm{~A}$ ). This is an additional argument in favor of a 150 largely uncoupled Lesser Antilles subduction interface, consistent with the low interseismic 151 coupling found using horizontal geodetic velocities only (van Rijsingen et al., 2021). Second, as 152 the three locking scenarios tested here contradict the observation of present-day subsidence of the 153 entire Lesser Antilles arc, we infer that such subsidence is not the result of seismic cycle-related 154 processes but rather of longer-term processes, which will be discussed below. 

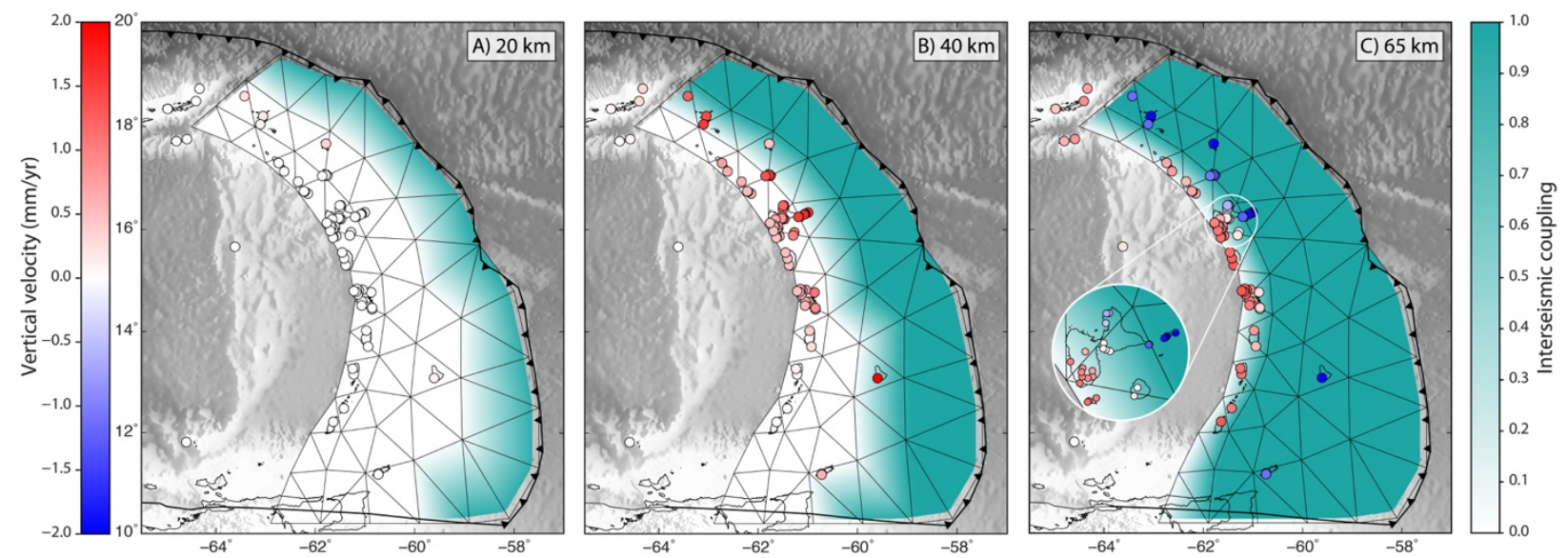

157 Figure 3. Predicted vertical motions for three scenarios of interseismic coupling: a downdip locking limit 158 of $20 \mathrm{~km}(\mathrm{~A}), 40 \mathrm{~km}(\mathrm{~B})$, and $65 \mathrm{~km}(\mathrm{C})$. The inset in $\mathrm{C}$ shows the transition from predicted subsidence to 159 uplift from NE to SW for the Guadeloupe Archipelago.

\section{LONG-TERM SUBSIDENCE ALONG THE ENTIRE MARGIN}

162 Figure 4 summarizes the observations of tectonic subsidence in the Lesser Antilles over a range of

163 time scales. We observe a long-term subsidence trend, though the rate derived from reef terraces 164 over $125 \mathrm{ka}$ is smaller than the more recent observations from micro-atolls and GNSS 165 observations. This could indicate an increase in subsidence rate since the last hundreds of

166 thousands of years, as suggested by Leclerc and Feuillet (2019). As this general subsidence cannot

167 be attributed to interseismic loading along the subduction megathrust, one must look into longer-

168 term processes. For instance, crustal faulting and volcano-related deformation (e.g., magmatic 169 chamber cooling or loading of volcanic edifices) may contribute to the observed subsidence, 170 although at rates that are too small to explain the observed amplitudes of 1-2 mm/yr (e.g., Leclerc 171 and Feuillet 2019). Variations in vertical motions between islands could also be attributed to an 172 interplay between local and regional deformation processes. This is probably the case for La 173 Désirade (a small island part of the Guadeloupe Archipelago) that has undergone substantial uplift 
174 in the Calabrian, followed by a decrease to negligible rates since $122 \mathrm{ka}$ possibly due to the 175 transient influence of the subducting Tiburon ridge (Figure 4; Léticée et al., 2019).

177 To better understand the apparent long-term, margin-wide subsidence of the Lesser Antilles, one 178 needs to zoom out and consider the geodynamic and tectonic context of the whole region. Since 179 the late Eocene ( $\sim 38 \mathrm{Ma})$, two main extensional phases occurred, first in a trench-parallel direction, 180 followed by trench-perpendicular extension that appears to be still active today (e.g., Boucard et 181 al., 2021). The trench-parallel extension most likely occurred in response to collision of the 182 Bahamas Bank with the Northeastern Caribbean Plate in late Paleocene-early Eocene times ( 56 $183 \mathrm{Ma}$ ), which caused a major plate reorganization, followed by progressive bending of the Lesser 184 Antilles trench into its current convex geometry (Cornée et al., 2021). The arc-perpendicular V185 shaped basins that formed in response to this are currently sealed and cross-cut by transverse faults 186 that accommodate ongoing arc-perpendicular extension since the mid-Miocene (Boucard et al., 187 2021). This second phase of extension is chronologically consistent with regional subsidence in 188 the northern- (forearc; Boucard et al., 2021, intra-arc; Cornée et al., 2021), central- (offshore 189 Guadeloupe; De Min et al., 2015) and southern part of the margin (back-arc basin; Garrocq et al., 190 2021). It is possible that the tectonic subsidence discussed here (Figure 4 ) for the more recent 191 times, including the Present, is the result of the on-going continuation of this post-mid-Miocene 192 extension.

194 In terms of processes, Boucard et al. (2021) argue that tectonic erosion is responsible for the forearc 195 subsidence, as well as for the landward migration of the Northern Lesser Antilles Arc from mid196 Miocene to Early Pliocene. Although such mechanism could play a role in the Northern Lesser 
197 Antilles, where the incoming plate is relatively rough, the 7-km-thick pile of trench sediments in 198 the South would certainly overcome any material lost by tectonic erosion (De Min et al., 2015).

199 Such discrepancy should result in along-arc variability of the subsidence rate that we do not 200 observe. In addition, tectonic erosion generally occurs within several kilometers of the trench 201 (Regalla et al., 2013), whereas the Lesser Antilles islands are located at $>170 \mathrm{~km}$ from the trench. 202 Alternatively, we suggest that the observed trench-perpendicular extension and margin-wide 203 subsidence are controlled by slab dynamics processes. Since the trench-perpendicular extension 204 (and related margin-wide subsidence) and the landward migration of the arc overlap in time (i.e., 205 from middle Miocene to Early Pliocene), a simple shallowing or steepening of the slab would not 206 explain both observations. More complex processes, such as slab unbending, or changes in slab 207 buoyancy would then be a plausible explanation (Buiter et al., 2001; Regalla et al., 2013). Such 208 processes could also play a role in tuning the aseismic character of the subduction megathrust 209 (Beall et al., 2021), which appears to be a longer-term feature.

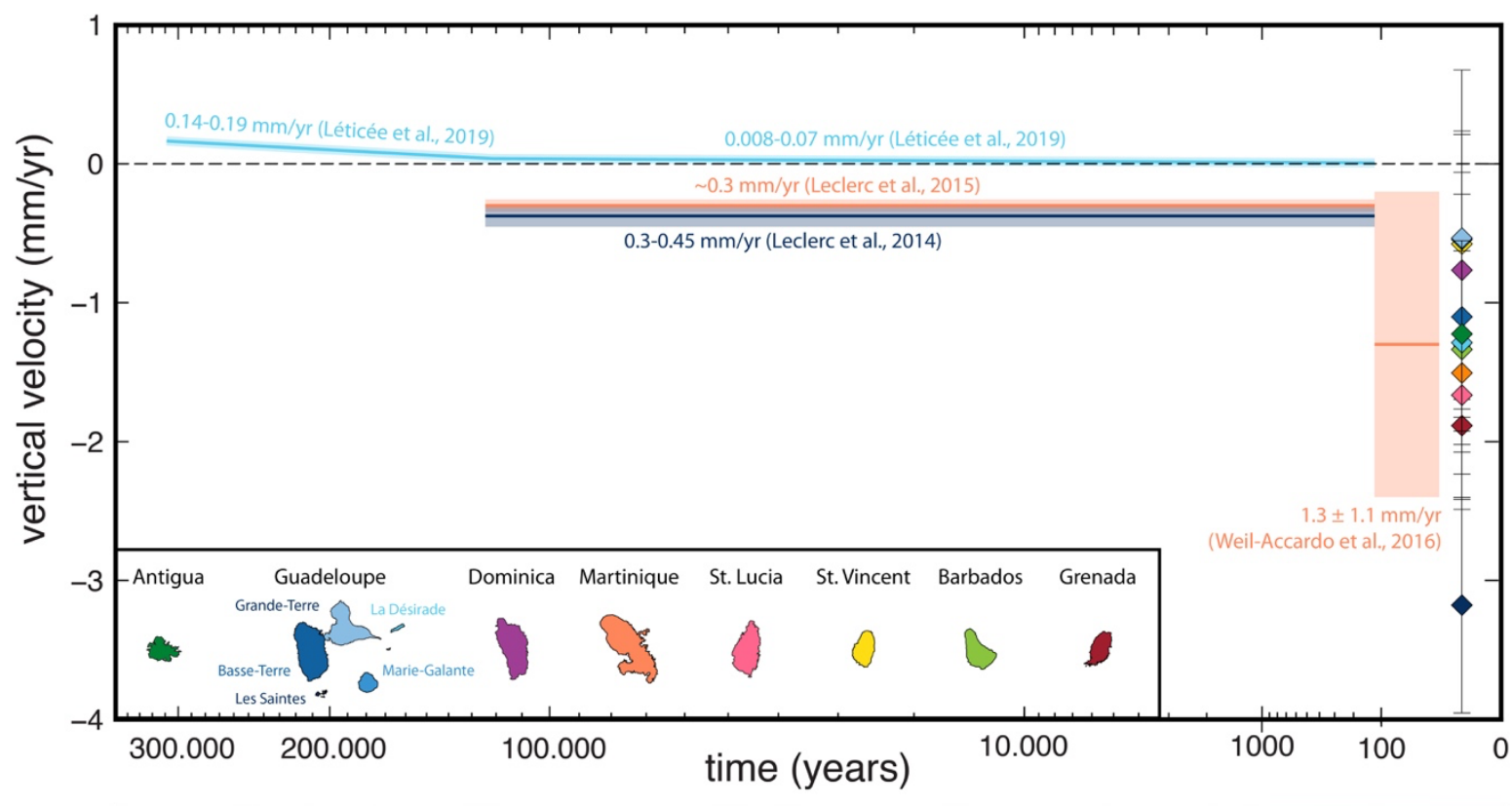


211 Figure 4. Overview of vertical tectonic motions on different time-scales, ranging from several tens of years

212 (right) to hundreds of thousands of years (left) and color-coded per island. Diamond symbols indicate the

213 weighted average velocities for all islands (modern geodesy; this study), while lines indicate estimates from

214 micro-atoll data (Weil-Accardo et al., 2016) and reef terraces (Leclerc et al., 2014; 2015, Léticée et al., 215 2019).

216

\section{ACKNOWLEDGMENTS}

218 We thank Serge Lallemand and Boris Marcaillou for helpful discussions. EvR and GNSS 219 campaigns were supported through the FEDER European Community program within the Interreg 220 Caraïbes "PREST" project and EC and RJ acknowledge support from the Institut Universitaire de 221 France. This project has received funding from the European Research Council (ERC) under the 222 European Union's Horizon 2020 research and innovation program (Grant Agreement 758210, 223 Geo4D project).

\section{REFERENCES CITED}

Armijo, R., Lacassin, R., Coudurier-Curveur, A., and Carrizo, D., 2015, Coupled tectonic evolution of Andean orogeny and global climate: Earth-Science Reviews, v. 143, p. 1-35, doi:10.1016/j.earscirev.2015.01.005.

Avouac, J.-P., 2015, From geodetic imaging of seismic and aseismic fault slip to dynamic modeling of the seismic cycle: Annual Review of Earth and Planetary Sciences, v. 4, p. 233-271, doi:10.1146/annurev-earth-060614-105302

Beall, A., Fagereng, Å., Davies, J. H., Garel, F., and Davies, D. R., 2021, Influence of 
Seismogenic Behavior: Geochemistry, Geophysics, Geosystems, v. 22, p. 1-20, doi: 10.1029/2020GC009267.

Bernard, P., \& Lambert, J., 1988, Subduction and seismic hazard in the northern Lesser Antilles: Revision of the historical seismicity: Bulletin of the Seismological Society of America, v. 78, p. $1965-1983$.

Bie. L., et al., 2020, Along-Arc Heterogeneity in Local Seismicity across the Lesser Antilles Subduction Zone from a Dense Ocean-Bottom Seismometer Network: Seismological Research Letters, v. 91, p. 237-247, doi:10.1785/0220190147.

Boucard, M. et al., in press, Paleogene V-shaped basins and Neogene subsidence of the Northern Lesser Antilles Forearc: Tectonics, doi:10.1029/2020TC006524.

Buiter, S. J. H., Govers, R., Wortel, M. J. R., 2001, A modelling study of vertical surface displacements at convergent plate margins: Geophysical Journal International, v. 147, p. 415-427, doi:10.1046/j.1365-246X.2001.00545.x

Chlieh, M., de Chabalier, J. B., Ruegg, J. C., Armijo R., Dmowska, R., Campos, J., and Feigl, K. L., 2004, Crustal deformation and fault slip during the seismic cycle in the North Chile subduction zone, from GPS and InSAR observations: Geophysical Journal International, v. 158, p. 695-711, doi:10.1111/j.1365-246X.2004.02326.x.

Cornée J.-J., et al., 2021, Lost islands in the northern Lesser Antilles : possible milestones in the Cenozoic dispersal of terrestrial organisms between South-America and the Greater Antilles: Earth-Science Reviews, doi:10.1016/j.earscirev.2021.103617

De Min, L., et al., 2015. Tectonic and sedimentary architecture of the Karukéra spur: A record of the Lesser Antilles fore-arc deformations since the Neogene: Marine Geology, v. 363, p. 15-37, doi:10.1016/j.margeo.2015.02.007. 
Garrocq, C., et al., 2021, Genetic Relations Between the Aves Ridge and the Grenada Back-Arc Basin, East Caribbean Sea: Journal of Geophysical Research: Solid Earth, v. 126, p. 1-29, doi:10.1029/2020JB020472.

Hayes, G.P., Moore, G. L., Portner, D. E., Hearne, M., Flamme, H., Furtney, M., and Smoczyk, G.M., 2018, Slab2, a comprehensive subduction zone geometry model: Science, v. 61, p.

Herring, T., 2003, MATLAB tools for viewing GPS velocities and time series: GPS Solutions, v. 7, p. 194-199, doi:10.1007/ s10291-003-0068-0

Heuret, A., Lallemand, S., Funiciello, F., Piromallo, C., and Faccenna, C., 2011, Physical characteristics of subduction interface type seismogenic zones revisited: Geochemistry, Geophysics, Geosystems, v. 12, p. 1-26, doi: 10.1029/2010GC003230.

Jolivet, R., Simons, M., Duputel, Z., Olive, J.-A., Bhat, H. S., and Bletery, Q., 2020, Interseismic Loading of Subduction Megathrusts Drives Long-Term Uplift in Nothern Chile:

Geophysical Research Letters, p. 1-11, doi:10.1029/2019GL085377.

Leclerc. F., et al., 2014, The Holocene drowned reef of Les Saintes plateau as witness of a longterm tectonic subsidence along the Lesser Antilles volcanic arc in Guadeloupe: Marine Geology, v. 355, p. 115-135, doi:10.1016/j.margeo.2014.05.017.

Leclerc, F., Feuillet, N., Perret, M., Cabioch, G., Bazin, S., Lebrun, J.-F., and Saurel, J.M., 2015,

Leclerc, F., and Feuillet, N., 2019, Quaternary coral reef complexes as powerful markers of long279 term subsidence related to deep processes at subduction zones: Insights from Les Saintes 
(Guadeloupe, French West Indies): Geosphere, v. 15, p. 983-1007, doi:10.1130/GES02069.1.

282 283

Léticée, J.-L., Cornée, J.-J., Münch, P., Fietzke, J., Philippon, M., Lebrun, J.-F., De Min, L., and Randrianasolo, A., 2019, Decreasing uplift rates and Pleistocene marine terraces settlement in the central lesser Antilles fore-arc (La Désirade Island, $16^{\circ} \mathrm{N}$ ): Quaternary International, v. 508, p. 43-59, doi:10.1016/j.quaint.2018.10.030.

Loveless, J. P. and Meade, B. J., 2011, Spatial correlation of interseismic coupling and coseismic rupture extent of the $2011 \mathrm{Mw}=9.0$ Tohoku-oki earthquake: Geophysical Research Letters, v. 38, p. 1-5, doi:10.1029/2011GL048561.

Manaker, D. M., Calais, E., Freed, A. M., Ali, S. T., Przybylski, P., Mattioli, G., Jansma., P., Prépetit, C., and Chabalier, J. B., 2008, Interseismic Plate coupling and strain partitioning in the Northeastern Caribbean: Geophysical Journal International. V. 174, p. 889-903, doi: 10.1111/j.1365-246X.2008.03819.x.

Menant, A., Angiboust, S., Gerya, T., Lacassin, R., Simoes, M., and Grandin, R., 2020, Transient stripping of subducting slabs controls periodic forearc uplift: Nature Communications, v. 11, p. 1-11, doi:10.1038/s41467-020-15580-7.

Mouslopoulou, V., Oncken, O., Hainzl, S., and Nicol, A., 2016, Uplift rate transients at subduction margins due to earthquake clustering: Tectonics, v. 35, p 23702384, doi:10.1002/2016TC004248.

Regalla, C., Fisher, D. M., Kirby, E., and Furlong, K., 2013, Relationship between outer forearc subsidence and plate boundary kinematics along the Northeast Japan convergent margin: Geochemistry, Geophysics, Geosystems, v. 14, p. 5227-5243, doi:10.1002/2013GC005008. 
303 Reilinger, R., et al., 2006, GPS constraints on continental deformation in the Africa-Arabia-

304 Eurasia continental collision zone and implications for the dynamics of plate interactions:

305 Journal of Geophysical Research, v. 111, p. 1-26, doi:10.1029/2005JB004051

306 van Rijsingen, E. M., Calais, E., Jolivet, R., de Chabalier, J.-B., Jara, J., Symithe, S., Robertson,

307 R., and Ryan, G. A., 2021, Inferring Interseismic Coupling Along the Lesser Antilles

308 Arc: A Bayesian Approach: Journal of Geophysical Research: Solid Earth, v. 126, p.1-21, 309 doi:10.1029/2020JB020677.

310 Sakic, P., Männel, B., Bradke, M., Ballu, V., de Chabalier, J.-B., and Lemarchand, A., 2020,

311 Estimation of Lesser Antilles Vertical Velocity Fields Using a GNSS-PPP Software

312 Comparison, in International Association of Geodesy Symposia: Springer, Berlin,

313 Heidelberg, p. 1-12, doi:10.1007/1345_2020_101.

314 Savage, J.C., 1983, A Dislocation Model of Strain Accumulation and Release at a Subduction

315 Zone: Journal of Geophysical Research, v. 88, p. 4984-4996,

316 doi:10.1029/JB088iB06p04984.

317 Schlaphorst, D., Melekhova, E., Kendall, J. M., Blundy, J., and Latchman, J., 2018, Probing

318 layered arc crust in the Lesser Antilles using receiver functions: Royal Society Open

319 Science, v. 5, p. 1-14, doi:10.1098/rsos.180764.

320 Sieh, K., et al., 2008, Earthquake Supercycles Inferred from Sea-Level Changes Recorded in the 321 Corals of West Sumatra: Science, v. 322, p. 1674-1678, doi:10.1126/science.1163589.

322 Symithe, S., Calais, E., de Chabalier, J. B., Robertson, R., and Higgins, M., 2015, Current block 323 motions and strain accumulation on active faults in the Caribbean: Journal of

324 Geophysical Research: Solid Earth, v. 120, p. 1-27, doi:10.1002/2014JB011779. 
325 Vannucchi, P., et al., 2013, Rapid pulses of uplift, subsidence, and subduction erosion offshore 326 Central America: Implications for building the rock record of convergent margins: 327 Geology, v. 41, p. 995-998, doi:10.1130/G34355.1.

328 Wallace, L.M., Fagereng, Å., and Ellis, S., 2012, Upper plate tectonic stress may influence 329 interseismic coupling on subduction megathrusts: Geology, v. 40, p. 895-898, $330 \quad$ doi:10.1130/G33373.1.

331 Weil-Accardo, J., Feuillet, N., Jacques, E., Deschamps, P., Beauducel, F., Cabioch, G., 332 Tapponnier, P., Saurel, J.-M., and Galetzka, J., 2016, Two hundred years of relative sea 333 level changes due to climate and megathrust tectonics recorded in coral microatolls of 334 Martinique (French West Indies): Journal of Geophysical Research: Solid Earth, v. 121, 335 p. 2873-2903, doi:10.1002/2015JB012406.

336 Zhu, L., and Rivera, L. A., 2002, A note on the dynamic and static displacements from a point 337 source in multilayered media: Geophysical Journal International, v. 148, p. 619-627, doi: 10.1046/j.1365-246X.2002.01610.x. 